\title{
Enhancing the potential of SMEs by using European funds in Romania
}

Simona MASCU ${ }^{1}$

\section{Manuela Liliana MURESAN ${ }^{2}$}

\begin{abstract}
The main objective of this article is the detailed approach of different concepts regarding the importance of small and medium enterprises in the contemporary economy in Romania, their role, place and specificity on the international markets.

The analysis focuses on the current state of SMEs in Romania, both from a perspective legislative and institutional aspects and aspects of their performance situation and the need to finance SMEs in Romania through the European Structural Funds.

Also, this article proposes a presentation of various reports and documents on the situation of SMEs in Romania and the European Union in recent years, with the emphasis on highlighting their importance and their contributions in the economic and social environment.
\end{abstract}

Keywords: SMEs, European funds, the enterprise, economy, Romania, European Union, business environment

JEL classification: $A 1, F 63, G 2, H 81, L 26, O 1$

DOI: $10.24818 /$ RMCI.2019.2.187

\section{Introduction}

Small and medium-sized enterprises (SMEs) are the basic structure of the economy and the main source of economic growth in both developed and lessdeveloped countries in Europe. These are very important at government level because of their potential to provide jobs for the population. However, gaps between regions are still significant in both Romania and the Member States of the European Union.

In Romania, the SME sector represents about $99.7 \%$ of the business population, and in Europe $99.8 \%$. A percentage of 93\% of non-financial firms are micro-enterprises with up to 10 employees. The population density of SMEs varies significantly between Member States. Romania ranks last, with only 2.2 SMEs / 100 inhabitants, which represents less than half of the EU average of 4.5 SMEs / 100 inhabitants.

${ }^{1}$ Simona Mascu, Tehnical University of Civil Engineering Bucharest, mascu_simona@ yahoo.com

2 Manuela Liliana Muresan, Bucharest University of Economic Studies, manumuresan@ gmail.com 
The main goal of the document is the detailed approach of different concepts regarding the importance of small and medium enterprises in the contemporary economy, their role, place and specificity on the international markets. Also, the secondary research objectives from the general objective are as follows:

$>$ The SME Development Coordinates in Romania (through the theoretical and methodological notions will be presented aspects related to: the definition and characteristics of small and medium enterprises, the role and place of SMEs in the contemporary economy, the current state of SMEs in Romania both from a perspective legislative and institutional aspects and aspects of their performance);

$>$ Financing of SMEs in Romania through the European Structural Funds (presentation of various reports and documents on the situation of SMEs in Romania and the European Union in recent years, with the emphasis on highlighting their importance and their contributions in the economic and social environment);

$>$ Current state of the absorption of European funds for SMEs in Romania;

$>$ Difficulties and barriers faced by SMEs in Romania in accessing European funds.

This paper proposes a selective bibliographic research that will highlight the scientific knowledge regarding the economic and social sector in the field of SMEs: analysis of different laws, reports, situations and documents regarding SMEs in Romania and the European Union. The aim of this research is to highlight the current situation and the need to finance SMEs from European and national sources as well as the expansion of domestic affairs in foreign markets.

\section{Literature review}

\subsection{Small and medium-sized enterprises - theoretical-methodological notions}

\subsubsection{Definition and characteristics of small and medium-sized enterprises}

In line with the definition given by the European Commission in Recommendation 2003/361 / EC, an enterprise is "any entity engaged in an economic activity, irrespective of its legal form". This wording reflects the terminology used in the decisions of the European Court of Justice and is formally included in the recommendation, and the purpose of the new definition of the SME is clearly highlighted. Small and medium-sized enterprises are divided into different forms of business in countries around the world, and without regulation, it is difficult to achieve the objective of welfare and economic growth. SMEs are broken down into micro, small and medium-sized enterprises and the SME status of an enterprise belonging to a group of enterprises can be determined on the basis of employee data, turnover and balance sheet across the group. Therefore, authorized individuals, family associations, partnerships and associations engaged in an economic activity 
can be considered as enterprises. The determining factor is economic activity, not legal form. ${ }^{3}$

SMEs are those enterprises employing less than 250 people with a turnover of less than 50 million EUR and / or a total balance sheet total of less than 43 million EUR. The SME Recommendation contains detailed group number guidelines to determine the SME status of an individual enterprise.

According to art. 2 of the Commission Recommendation, company data, should be analyzed according to the following three criteria:

\section{$>$ Average number of employees, \\ $>$ annual turnover, \\ $>$ the total annual balance sheet.}

Small enterprises are defined as enterprises with fewer than 50 employees and which achieve an annual turnover or a total annual balance sheet total of up to 10 million EUR. Microenterprises are defined as enterprises that have fewer than 10 employees and achieve an annual turnover or total annual balance of up to 2 million.

Net annual turnover is determined by calculating the revenue the enterprise achieves in one year of sales and services after all debts have been paid. This should not include VAT or other indirect taxes. The balance sheet total refers to the value of the company's main assets. If the enterprise exceeds the financial ceilings set for its turnover and total balance sheet and caps for the average number of employees in a year, this will not affect the company's situation. It will retain its SME status with which the year began. However, it will lose this status if the ceiling is exceeded during two consecutive annual financial years. In the same way, it will earn the status of an SME if it was a large enterprise in the previous period but then dropped below these ceilings during two consecutive financial years.

Table 1 Applying the new definition of SMEs

\begin{tabular}{|c|c|l|l|}
\hline $\begin{array}{c}\text { Category of } \\
\text { SMEs }\end{array}$ & $\begin{array}{c}\text { Number of employees } \\
\text { Annual work unit (AWU) }\end{array}$ & Annual turnover & $\begin{array}{c}\text { The total annual } \\
\text { balance sheet }\end{array}$ \\
\hline \multirow{2}{*}{ Medium } & $<250$ & $\begin{array}{l}\leq 50 \text { millions } € \\
\text { (in 1996 }- \\
50 \text { millions) }\end{array}$ & $\begin{array}{l}\leq 43 \text { millions } € \\
\text { (in 1996 - } \\
27 \text { millions } €\end{array}$ \\
\hline Small & $<50$ & $\begin{array}{l}\leq 10 \text { millions } € \\
\text { (in 1996 }-7 \\
\text { millions } € \text { ) }\end{array}$ & $\begin{array}{l}\leq 10 \text { millions } € \\
\text { (in 1996 }- \\
5 \text { millions } € \text { ) }\end{array}$ \\
\hline Micro & $<10$ & $\begin{array}{l}\leq 2 \text { millions } € \\
\text { (previously } \\
\text { undefined) }\end{array}$ & $\begin{array}{l}\leq 2 \text { millions } € \\
\text { (previously } \\
\text { undefined) }\end{array}$ \\
\hline
\end{tabular}

Source: Recomandation 2003/361 / CE Article 2. Application of new definition of SMEs. New ceilings

${ }^{3}$ Art. 1, Recomandation 2003/361 / CE 
In order to promote innovation and improve access to research and development, specific provisions apply to universities and non-profit development centers, giving them the opportunity to make a financial contribution to an SME. Both sides will benefit from this collaboration. It strengthens an enterprise by offering a trusted financial partner and access to research and development. It also provides research centers with an opportunity to implement their innovation work.

\section{Findings}

\subsection{The Role and Place of SMEs in the Contemporary Economy}

In recent years, even if multinational and transnational affairs in Romania are more present than in the past, small and medium-sized enterprises (SMEs) play the most important role in economic growth and job creation (Marcketti \& Kozar, 2017). In addition, Romania must prioritize market opportunities and move towards internationalization, given that economic and political stability combined with a high-end infrastructure provides a growth-friendly ecosystem. They help reduce the unemployment rate as it creates jobs for the community and thus increases economic growth (Faizan, Jabar, Tajuddin \& Paino, 2016).

The amplification of domestic demand and the penetration of new markets were the main business opportunities for small and medium-sized companies in 2018, according to the 16th edition of the Romanian version of which was launched by the National Small Business Council and Mediation in Romania (CNIPMMR), in partnership with the Ministry of Business, Commerce and Entrepreneurship (MMACA). This is a reference in the literature, both in Romania and at the level of the European Union, representing the most in-depth analysis of the SME sector in our country. The "White Paper of SMEs in Romania" highlights quantitatively and qualitatively the situation, the trends, the perception of the business environment and is the basis for proposing strategies regarding the future directions of support and development of the Romanian business environment.

The importance of SMEs has begun to emerge in particular since the 1970s, and in the 1980s they experienced a significant expansion, their share growing significantly in both Europe and the United States and Japan. However, SMEs have always faced pressures in various forms.

\subsection{SME Development Coordinates in Romania}

The current prerequisites for the development of SMEs in Romania imply the creation of an operational framework favorable to the economic development in Romania and the stimulation of the business environment, the reduction of unemployment through the creation of new jobs, the stimulation of the entrepreneurial spirit through the establishment of new small and medium enterprises. At present, there is a significant reduction in the number of SMEs, mainly due to the acute shortage of funding by tightening lending conditions in general, increasing the difficulties and risks of starting a business. 
Although the population density of SMEs varies greatly between Member States, Romania ranks last, with only 2.2 SMEs / 100 inhabitants, which represents less than half of the EU average of 4.5 SMEs / 100 inhabitants (Ordinance of expedition, 2017).

Table 2. DENSITY OF SMEs at county level in Romania

\begin{tabular}{|c|c|c|c|}
\hline $\begin{array}{l}\text { Macroregions, } \\
\text { development regions and } \\
\text { counties }\end{array}$ & Total SME (nr.) & $\begin{array}{l}\text { Resident } \\
\text { population at 1st of } \\
\text { Jan. (nr. persons) }\end{array}$ & $\begin{array}{l}\text { SME Density (nr. } \\
\text { SME/ } 100 \text { residents) }\end{array}$ \\
\hline & (a) & (b) & $(c)=(a)+(b)$ \\
\hline Bihor & 17,945 & 568,969 & 3.15 \\
\hline Bistrita-Nasaud & 6,483 & 282,495 & 2.29 \\
\hline Cluj & 29,669 & 701,258 & 4.23 \\
\hline Maramures & 10,326 & 468,333 & 2.20 \\
\hline Satu Mare & 7,469 & 338,181 & 2.21 \\
\hline Salaj & 4,888 & 217,331 & 2.25 \\
\hline Alba & 7,894 & 333,488 & 2.37 \\
\hline Brasov & 18,661 & 550,934 & 3.39 \\
\hline Covasna & 3,776 & 206,279 & 1.83 \\
\hline Harghita & 7,142 & 307,555 & 2.32 \\
\hline Mures & 12,961 & 543,726 & 2.38 \\
\hline Sibiu & 10,790 & 399,982 & 2.70 \\
\hline Bacau & 11,129 & 600,549 & 1.85 \\
\hline Botosani & 4,031 & 394,625 & 1.02 \\
\hline Iasi & 15,775 & 788,659 & 2.00 \\
\hline Neamt & 8,640 & 455,643 & 1.90 \\
\hline Suceava & 11,385 & 629,733 & 1.81 \\
\hline Vaslui & 4,893 & 387,525 & 1.26 \\
\hline Braila & 6,142 & 303,608 & 2.02 \\
\hline Buzau & 9,205 & 431,015 & 2.14 \\
\hline Constanta & 20,783 & 681,054 & 3.05 \\
\hline Galati & 11,778 & 520,058 & 2.26 \\
\hline Tulcea & 4,655 & 203,196 & 2.29 \\
\hline Vrancea & 6,293 & 330,937 & 1.90 \\
\hline Arges & 14,931 & 595,764 & 2.51 \\
\hline Calarasi & 4,563 & 295,505 & 1.54 \\
\hline
\end{tabular}




\begin{tabular}{|c|c|c|c|}
\hline $\begin{array}{l}\text { Macroregions, } \\
\text { development regions and } \\
\text { counties }\end{array}$ & Total SME (nr.) & $\begin{array}{l}\text { Resident } \\
\text { population at 1st of } \\
\text { Jan. (nr. persons) }\end{array}$ & $\begin{array}{l}\text { SME Density (nr. } \\
\text { SME/ 100 residents) }\end{array}$ \\
\hline Dambovita & 7,241 & 505,219 & 1.43 \\
\hline Giurgiu & 4,468 & 274,570 & 1.63 \\
\hline Ialomita & 4,175 & 264,733 & 1.58 \\
\hline Prahova & 16,547 & 740,483 & 2.23 \\
\hline Teleorman & 4,983 & 355,281 & 1.40 \\
\hline Ilfov & 20,912 & 444,241 & 4.71 \\
\hline Bucuresti & 110,422 & $1,843,962$ & 5.99 \\
\hline Dolj & 14,195 & 641,040 & 2.21 \\
\hline Gorj & 6,074 & 327,537 & 1.85 \\
\hline Mehedinti & 3,255 & 252,600 & 1.29 \\
\hline Olt & 6,604 & 412,491 & 1.60 \\
\hline Valcea & 7,193 & 359,814 & 2.00 \\
\hline Arad & 11,336 & 424,075 & 2.67 \\
\hline Caras-Severin & 4,627 & 282,467 & 1.64 \\
\hline Hunedoara & 8,671 & 398,950 & 2.17 \\
\hline Timis & 23,151 & 696,720 & 3.32 \\
\hline Data & & & \\
\hline
\end{tabular}

Source: Data are provided by the National Institute of Statistics

\subsection{Financing SMEs in Romania through European Structural Funds}

\subsubsection{SME financing modalities}

At this time, many SMEs in Romania report difficulties in accessing bank loans. The main causes are the lack of guarantees and the high cost of credits. These barriers can be removed by using European SME Guarantee Instruments. Access to capital is a permanent problem for SMEs, in particular because they cannot provide the guarantees that lenders traditionally require. To address this, the new definition facilitates equity financing for SMEs by favouring certain investors, such as regional funds, venture capital and business angels, without companies losing their status by SMEs. The same principle applies to local autonomous authorities with an annual budget of up to 10 million EUR and less than 5000 inhabitants. They can invest a certain percentage in an SME without the company being disadvantaged when applying for grants.

Small and medium-sized enterprises (SMEs) are the backbone of the European economy, providing the newest jobs. The European Commission aims to promote entrepreneurship and improve the business environment for SMEs to enable them to realize their full potential in the global economy today. The new Small and 
Medium Enterprises Competitiveness (COSME) program will run 2014-2020 with a planned budget of 2.5 billion EUR (Eurostat, 2018).

Access to finance is the most important concern for $7 \%$ of SMEs in the EU. It decreased from $16 \%$ in 2009 to $14 \%$ in 2013. Generally, SMEs in the European Union in 2018 reported as the three most important issues: availability of qualified staff or experienced managers, customer finding and regulation (for example: laws, industrial regulations, etc.), (European Commission, 2015).

Figure 1. Evolution of access to finance as the most important problem for SMEs

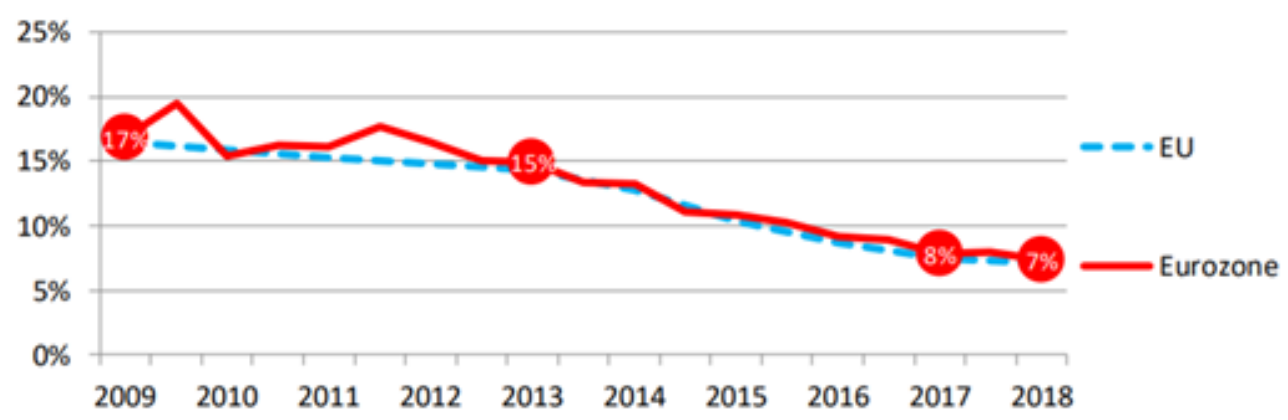

Source: Eurostat, 2018

In the European Union, SMEs that have participated in the opinion poll on past or future business financing have reported that the most important sources of funding are credit lines (relevant to 52\% of SMEs), leasing (47\%) and bank credits (47\%). Share-based financing is relevant for $12 \%$ of EU SMEs. Over the past 6 months, they have most often used credit lines (35\% for business implementation).

Figure 2. The most important sources of financing for SMEs

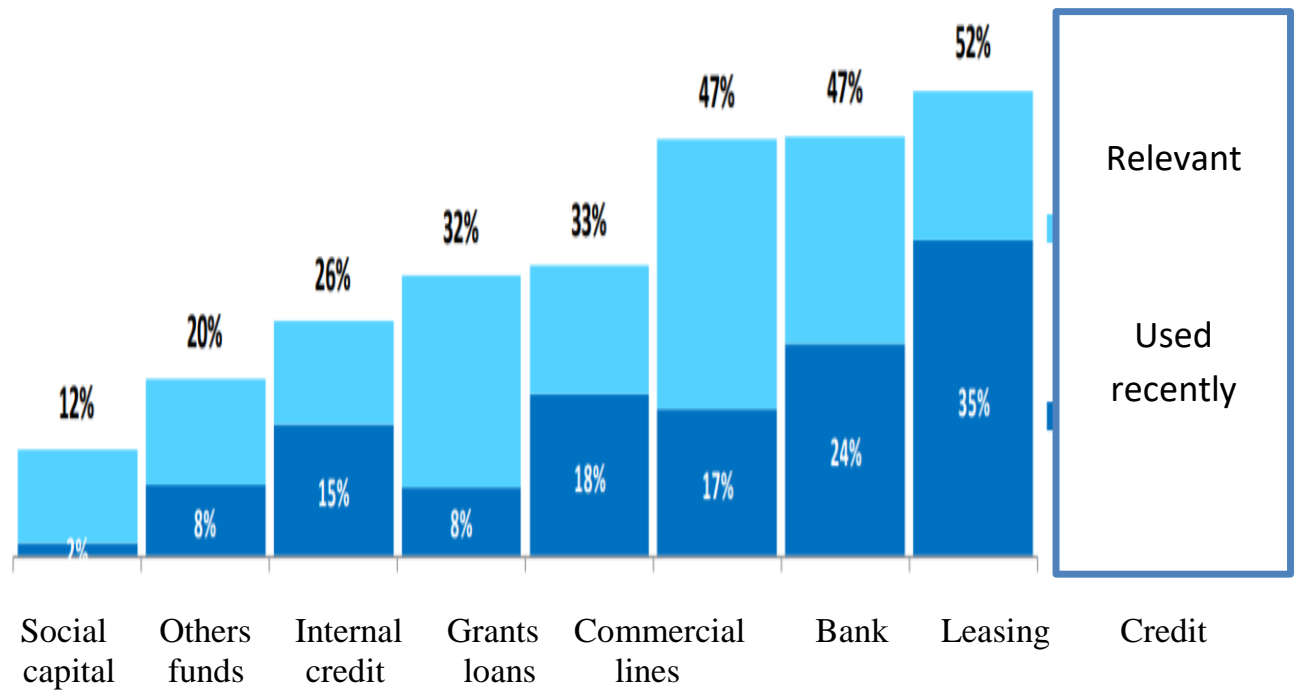

Source: Eurostat, 2018 
Access to finance for SMEs is done through funding lines and several types of European or governmental programs, such as:

- National Emergency Credit Guarantee Fund (FNGCIMM): IMM Invest Romania Program;

- EBRD advice for SMEs - Facilitating the export of SMEs;

- Competitiveness Program for enterprises and SMEs - COSME;

- Internationalization Program 2017-2018;

- EU funds for START-UP 2018: START-UP Diaspora and Romania START-UP PLUS;

- European funds for IT companies;

- Non-reimbursable funds for agro-food production;

- Start-Up Nation;

- Start-Up City;

- European funds of max. 5 million Euro each SME;

- Loans with EU guarantees;

- Romanian investment funds;

- Google Funds (Startupcafe, 2019).

Keeping in view of the small percentage of entrepreneurs financing their activity through bank loans, but also the objectives of many SMEs to expand their business in the coming years, guarantee instruments, such as the SME Initiative (SMEI), can represent solutions that could be successfully implemented by these companies. Specific actions have been taken to support the promotion of entrepreneurship in the light of the Small Business Act (SBA): measures have been taken to reduce the time needed to obtain licenses and permits to initiate and carry out the specific activity of an enterprise, in view of the objectives of the SBA.

\subsubsection{Current state of play regarding the absorption of European funds for SMEs}

Considering that SMEs benefited from support through business incubation structures, this was insufficient: although there are more such structures at national level, only 10 business incubators were accredited and monitored in 2012, of which only 7 functional, supporting 149 SMEs with 327 jobs. According to the studies in the field, SMEs supported by incubators should be much less prone to the risk of failure in the first years of activity after their establishment due to the numerous services that these structures should provide. The SME sector can be characterized by relatively weak orientation towards productive activities, reduced access to capital, technology and infrastructure, aspects that negatively affect economic productivity.

For the local and regional communities in which they operate, SMEs are key to the welfare of the inhabitants but also important social stability factors. In order to boost entrepreneurship, it is necessary to directly support SMEs in their first years of activity and to create and develop those structures that support SMEs in the various stages of growth by providing SMEs with the services they need to operate 
in optimal parameters, the aim of increasing the survival rate of SMEs in the first years of operation.

As can be seen in Table 3, the absorption of European funds is not at a stage favourable to the development of the SME sector, if Romania managed to attract only 45.7 billion EUR from the EU over a period of 10 years, from which he returned back to the EU budget about 15.3 billion euros. This aspect is an alarming signal to the Romanian business environment in order to be more receptive both to legislation, as access to funds, and better informed when applying for an external financing line.

Table 3. Absorption of EU funds (2007-2017)

\begin{tabular}{|c|c|c|c|}
\hline \multicolumn{2}{|c|}{ How much we receive } & \multicolumn{2}{|c|}{ How much we gave } \\
\hline Year & $\begin{array}{c}\text { Amounts received } \\
\text { from EU } \\
\text { (billion. Euro) }\end{array}$ & $\begin{array}{c}\text { AMOUNTS PAYABLE to } \\
\text { the EU budget } \\
\text { (billion. Euro) }\end{array}$ & $\begin{array}{c}\text { Positive balance } \\
\text { (billion. Euro) }\end{array}$ \\
\hline 2007 & 1,6 & 1,1 & 0,5 \\
\hline 2008 & 2,6 & 1,3 & 1,3 \\
\hline 2009 & 2,8 & 1,3 & 1,5 \\
\hline 2010 & 2,3 & 1,2 & 1,1 \\
\hline 2011 & 2,6 & 1,3 & 1,3 \\
\hline 2012 & 3,4 & 1,4 & 2 \\
\hline 2013 & 6,5 & 1,4 & 4,3 \\
\hline 2014 & 5,9 & 1,6 & 5 \\
\hline 2015 & 6,4 & 1,4 & 5,9 \\
\hline 2016 & 7,4 & 1,5 & 3,3 \\
\hline 2017 & 4,8 & 1,5 & 30,4 \\
\hline TOTAL & 45,7 & 15,3 & \\
\hline
\end{tabular}

Source: Ministry of Public Finance

\subsubsection{Difficulties and barriers faced by SMEs in Romania in accessing European funds}

While entrepreneurship is the only area where the country is above the EU average, Romania is in line with the EU average for "a second chance". Romania also has the lowest scores in the EU for the single market, skills and innovation and the environment. In 2016 and in the first quarter of 2017, a significant number of policy measures have been implemented in 9 out of the 10 policy areas of the SBA, including in areas where score performance is still low, such as skills and innovation. Nonetheless, SME stakeholders say that overall progress on the implementation of the SBA in Romania was moderate.

Although progress has been made, Romania shows serious competitiveness gaps compared to EU countries, at the level of accessing structural funds, reflected in low productivity, which defines the issue of competitiveness and an increase in the absorption process.

Economic competitiveness is based on determinants at macro level - on components of institutions, public finance, infrastructure, etc., as well as at microbusiness level, SME dynamics, entrepreneurship, innovation activity, clustering, 
business network development. Increasing the competitiveness of SMEs becomes a key element in addressing the objectives of the EU 2020 Strategy, given that $99 \%$ of EU businesses are SMEs.

\section{Conclusions}

The economic development in a competitive market at the national and international level of SMEs can be achieved by increasing the access of European funds (financing programs on different sectors of activity) as a logical solution in this aspect, the same can be said educational, medical, etc.

As can be seen from the analysis of the available data, the Romanian entrepreneurial environment is in the "second chance" stage, so the governmental and private environment must join forces to create a plan to absorb European funding, especially for the main six sectors of the national economy. Not forgetting the factors that have led to this state of affairs: lack of innovation capacity, concentration of SMEs in sectors with low added value, difficult access to finance and poor management of SMEs.

In order to support entrepreneurship in Romania, authorities need to take action to increase the competitiveness and attractiveness of the business environment, including through institutional and legislative reforms and by promoting a transparent and stable fiscal environment, as well as the extremely low importance given entrepreneurial education and the ways of accessing the structural funds in the education system, which has direct repercussions on the quality of daily life of Romanians (Armeanu, Istudor \& Lache, 2014).

\section{References}

Armeanu, D., Istudor, N. and Lache, L., 2014. The role of SMEs in assessing the contribution of entrepreneurship to GDP in the Romanian business environment. Amfiteatru Economic, 17(38), pp. 198-215

Comisia Europeana (2015) https://ec.europa.eu/regional_policy/sources /conferences/state aid/sme/smedefinitionguide_en.pdf, last visited on 11.05.19;

Eurostat, 2018, https://ec.europa.eu/eurostat/statistics explained/index.php?title =Statistics_on_small_and_medium sized_enterprises\#SME_definition; last visited on 11.05.19;

Faizan Hj Abd Jabar, Norulhuda Tajuddin, and Halil Paino (2016) Internationalization of Small and Medium Enterprises, Springer Science+Business Media Singapore, Proceedings of the ASEAN Entrepreneurship Conference 2014, DOI 10.1007/978-981-10-0036-2_14;

INSS, http://www.insse.ro/cms/, last visited on 11.05.19;

Marcketti SB, Kozar MJ (2007), Leading with relationship a small firm example. Learn Org 14(2):142-153; 
Ministerul Finanțelor, http://www.mfinante.gov.ro/pagina.html?categoriebunuri= asistenta-nerambursabila-ue, comunicate-ue, programe, livrabile-proiectemfp-cofinantate-prin-podca-2007-2013\&pagina=ue\&menu=asistenta; last visited on 11.05.19;

Ordinance of expedition (2017), for the amendment and completion of the Emergency Ordinance no. 10/2017 to stimulate the establishment of new small and medium-sized enterprises, with subsequent amendments and completions; http://legislatie.just.ro/Public/DetaliiDocument/186184, last visited on 11.05.19;

Startup, https://www.startupcafe.ro/finantari/start-nation-start-plus-fondurieuropene-nerambursabile.htm, last visited on 11.05.19;

The European Commission, through Recommendation 2003/361/EC, https://lege5.ro/Gratuit/gi3tamjvgu/recomandarea-nr-361-2003-privinddefinirea-microintreprinderilor-si-a-intreprinderilor-mici-si-mijlociinotificata-cu-numarul-c-2003-1422-text-cu-relevanta-pentru-see, last visited on 11.05.19;

The white paper of SMEs, (2018), http://www.ceccarbusinessmagazine.ro/a-xvi-aeditie-a-cartei-albe-a-imm-urilor-din-romania-a3716/, last visited on 11.05.19. 